\title{
Restoration of a tropical island: Cousine Island, Seychelles
}

\author{
Michael J. Samways \\ Department of Conservation Ecology and Entomology and Centre for Invasion Biology, Stellenbosch \\ University, Matieland, 7612, South Africa \\ Peter M. Hitchins \\ P.O. Box 101834, Meer en See, 3901, South Africa \\ Orty Bourquin \\ 172 Stillwater Loop, Columbus, MT 59019, USA \\ Jock Henwood \\ P.O. Box 977, Cousine Island, Victoria, Mahé, Seychelles
}

\begin{abstract}
Tropical island species and ecosystems are threatened worldwide as a result of increasing human pressure. Yet some of these islands also lend themselves to restoration, as they are physically defined units that can be given focused attention, as long as resources are available and clear conservation targets are set. Cousine Island, Seychelles, is a tropical island that has received such intensive restoration. From a highly degraded island in the 1960s, the island has now been restored to what is believed to be a semblance of the natural state. All alien vertebrates have been eradicated, as have 25 invasive alien plants. Cultivated plants are now confined to one small section of the island. Poaching of nesting marine turtles has been stopped, leading to an increase in turtle breeding numbers. The shearwater population has increased in size with poaching activities under control. The Sooty tern has also returned to the island to breed. The coastal plain has been restored with over 2,500 indigenous shrubs and trees, which have now grown into a forest carpet. There are strict quarantine procedures on the island, keeping it free of rats, mice, various alien invertebrates and potentially invasive alien plants. Three threatened Seychelles endemic land birds (Seychelles warbler, Seychelles magpie robin and Seychelles white-eye) have been introduced and are thriving, with these introductions contributing to both the magpie robin and the white-eye being downgraded from CR to EN (the warbler remains at VU). Ecotourism, and nature conservation for the local inhabitants, have been introduced in a way that does not reduce the improved compositional, structural and functional biodiversity of the island. The result of the restoration effort appears to be sustainable in the long term, although challenges still remain, especially with regards to adequate clean water and a non-polluting power supply on the island. Cousine is thus paving the way in the art and science of tropical island restoration as a legacy for future generations.
\end{abstract}

Keywords: Tropical islands, Restoration, Seychelles, Cousine Island.

This paper is dedicated to Fred Keeley, patron of Cousine Island, whose insight bequeaths to future generations a jewel of an island.

\section{Introduction}

Tropical islands worldwide are undergoing an erosion of their indigenous biodiversity from various, often synergistic, impacts (Primack 2006). With their generally simple food webs, honed by local selection pressures, they are often highly susceptible to novel pressures. The impact caused by invasive alien organisms, in combination with other threats, may even lead to a 'meltdown' of the ecological character of the island (O'Dowd et al. 2003).

While there has been much focus on negative impacts on tropical islands, very little attention has been given to their restoration. Indeed, there have been few attempts around the world to totally restore a whole island. Here, we review the restoration of a 27 ha island, Cousine, in the Seychelles. 
The reason for this focus is to demonstrate that with determined effort, it is indeed possible to reverse the devastation so often seen on small tropical islands.

Any planned restoration project has a particular starting point and a goal. This applies to islands as much as anywhere else. The starting point here is the condition and composition of an island's current ecosystem (Samways 2000). Some islands have been through a catastrophic regime shift (Scheffer and Carpenter 2003) where restoration can never achieve the 'original state', as former inhabitants are now extinct, and the island is on a new ecological trajectory. Easter Island is a case in point (Bahn and Flenley 1992). On the other hand, some islands have the ingredients for recovery, including an absence of certain keystone invasive alien species (Samways 2000).

Prior to the early 1970 s, Cousine Island was partially highly denuded of woody vegetation and had been exploited agriculturally. Nevertheless, there were remnants of the original ecosystem that formed a baseline for recovery (Fig. 1). This was largely because it has granite outcrops among which many indigenous plants and animals still existed, albeit at much reduced population levels. In addition, Cousine had the very good fortune of apparently never having had rats or mice, nor the aggressive crazy ant (Anoplolepis gracilipes) (Hill et al. 2003). This no doubt was partly due to the fact that the island has always had a low human visitation rate coupled to sparse surface water supplies.

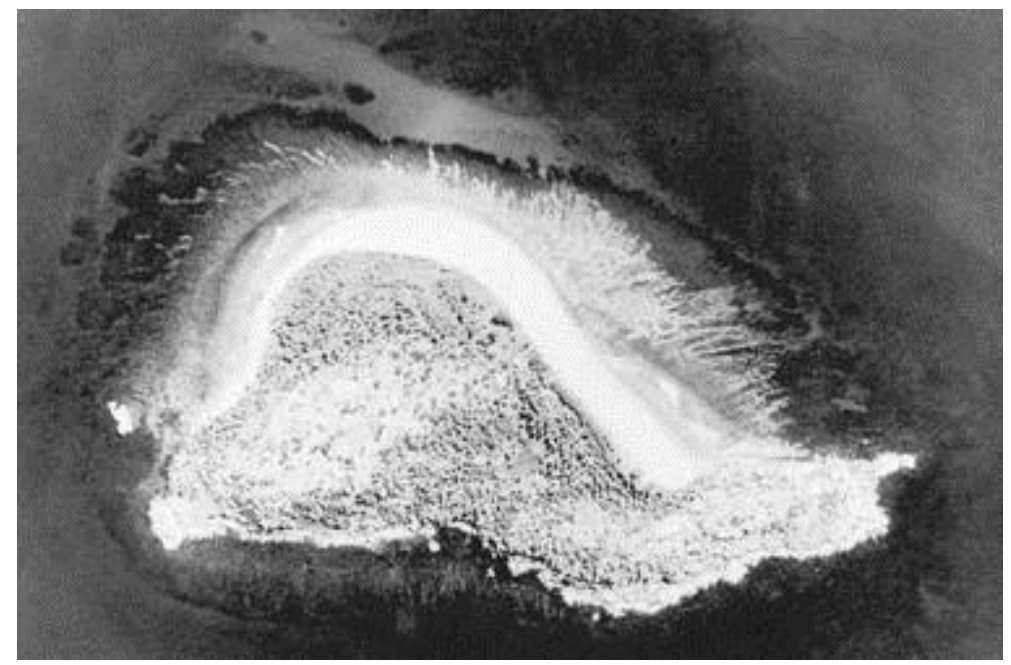

Fig. 1

Cousine Island, seen here in the 1960s, was overgrazed, planted to alien crops and largely denuded of indigenous vegetation, which only remained in pockets

Nevertheless, while Cousine presented a good case for restoration, there were many restoration management decisions that had to be made. These are embedded in Cousine's Mission Statement "To promote and practice nature conservation and the wise use of natural resources of the island and its surroundings" (Hitchins and Bourquin 1995).

It is worth mentioning here the significance of "surroundings". Any small island is in intimate contact with its marine matrix (Polis and Hurd 1996). For Cousine, this is manifested in particular by the influx of nesting sea birds. Their arrival brings nutrients, which improve the poor soil, and, in turn, support the plants and the animals of this ecosystem, including the endemic skinks (Ball 2001). Furthermore, Cousine is part of the granitic Seychelles archipelago, and its restoration goes hand in hand with conservation of neighbouring islands. With good planning, it is a win-win situation, where advice can be exchanged, species translocated and metapopulation dynamics continued.

In general terms, there have been three phases in the restoration of Cousine: (1) mid-1970s to early 1990s, 'partial clean up' phase, (2) early 1990s to late 1990s, 'poaching controls, major alien plant removal, replanting with indigenous vegetation, initiation of monitoring programmes, and first reintroductions' phase, and (3) 2000s, 'follow-up alien plant removal, continued indigenous plant establishment, second re-introductions phase'. Throughout all these stages, research, information gathering and planning were in effect. While the first two stages involved very minor ecotourism, the third phase introduced ecotourism as a means of the island 'paying its way' (Klocke and Klocke 2006). 
Hand in hand with this increase in visitors, is the development of more eco-friendly methods of generating power on the island, particularly the use of wind turbines to reduce the consumption of diesel fuel. Cousine, in co-operation with the local NGO Nature Seychelles, and a World Bankadministered GEF fund, built a conservation and education centre on the neighbouring island of Praslin. This enables local school learners, adults and tourists, to see what has been achieved on the islands of Cousine and Cousin. It also allows learners to be educated about Cousine, if it is not possible for them to visit the island.

There is one further introductory comment of global significance. World wide, there is an 'extinction of experience' (Miller 2005). That is, the cultural loss of the experience of nature. This is being remedied in urban areas with the development of ecological landscape planning. However, as biologists know, while it may well be possible to green urban areas and encourage the return of some wildlife, such species are mostly widespread generalists, well-adapted to living in disturbed conditions. The real key with rescuing the extinction of experience is to bring back the rare and threatened species in their natural setting (Samways 2007). This is where Cousine made an enormous contribution. One simply has to step onto the island to see, hear and smell the myriad of seabirds, extremely rare land birds, as well as many other forms of teeming wildlife. In short, the island is now a safe haven, and is a tropical island experiential paradise.

The detailed philosophy surrounding the second, planned phase of the restoration began in the early 1990s. Nevertheless, it is appropriate firstly to briefly review the early 'clean up phase', when a broad brush attempt was made to deal with some of the pressing issues facing the island.

\section{The early phase of restoration}

In the early twentieth century, Cousine Island was covered with coconut plantations (Diamond 1975). At various times it also had various other crop plants, including tobacco and cotton, all of which were grown wherever suitable, and with little regard to conservation of natural resources on the island (Fig. 2).

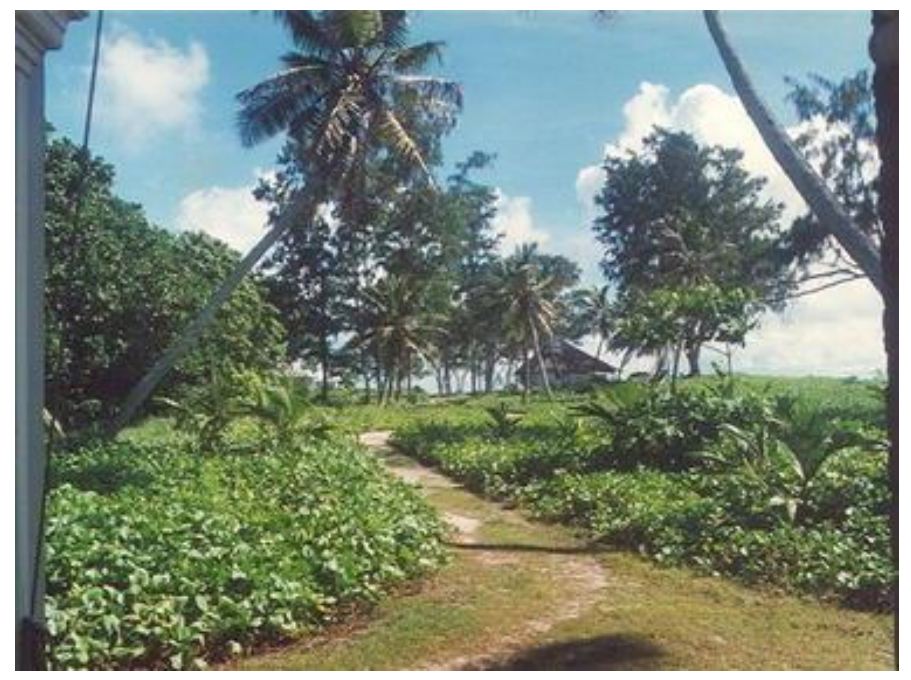

Fig. 2

By the mid-1990s, the plateau on Cousine Island had a vegetation cover but mostly of alien plants, many of which had been harvested in earlier years

Various livestock was also kept on the island, including cattle, pigs and chickens. Feral cats were also present, as were domestic dogs. One of the greatest concerns was the heavy poaching of shearwaters (up to 8,000 chicks per season) (Puffinus pacificus and P. Iherminieri) and turtles (Eretmochelys imbricata and Chelonia mydas), as well as the legal (at the time) harvesting of Sooty tern (Sterna fuscata) eggs of up to 30,000 per season.

The early clean up phase involved putting a stop to poaching of all indigenous wildlife, ad hoc removal of some of the lowland coconut trees, and eradication of the cats (81 in total, using traps and the poison "1080") and domestic livestock. Although some progress in terms of restoration was made by the early 1990s, it largely came to fruition only from the mid 1990s. 
During the 1970s, new villas were constructed on the hillside, but the rock blasting required for their construction resulted in loss of an introduced population of the Seychelles warbler (Acrocephalus sechellensis) which was re-introduced in June 1990 (Komdeur 1994). The bird has since thrived on the island, the current estimate being 350-400 birds on Cousine. However, owing to it still being threatened elsewhere in the archipelago, it is retained as VU on the IUCN Red List

\section{Second phase of restoration}

This phase began in 1995, with the long-term aim of restoring the coastal plain to what was believed to be its former natural state. Estimation of the original coastal vegetation was done by surveying the natural coastal vegetation remnants on the neighbouring islands of Cousin, Aride and Praslin.

Coupled to this baseline study were surveys of seeds that washed up onto the drift line of the beach, as this appeared to be a method by which seeds appear on the various Seychelles islands. Seeds dropped by the visiting Seychelles fruit bats (Pteropus seychellensis) from Praslin Island were also monitored.

A scientifically based management plan was then put in place, which combined various activities. These included intense removal programme against some of the most ecologically significant invasive alien plants to the island, as well as all the 243 planted individuals of Casuarina (Casuarina equisetifolia), which dominated the plain and dune crest. Areas were also cleared to encourage nesting by the Sooty tern. At the same time, a propagation programme was established to provide seedlings for planting on the plain. All progress was monitored. While much of the activity was carried out by the resident staff on the island, international volunteers were also involved. During this time, and continuing today, is also the ongoing removal of alien birds such as the Barn owl (Tyto alba) and the Indian mynah (Acridotheres tristis). Poaching was also monitored coupled to antipoaching initiatives. Strict quarantine of incoming goods and equipment was also introduced, with particular focus on aliens such as rats, mice, crazy ants and any invasive alien plants. Non-disturbance of the nesting seabirds was also enforced.

Throughout this time, plans were also being put in place to re-introduce certain highly threatened, Seychelles endemic land birds, primarily the Seychelles magpie robin (Copsychus sechellarum) (Komdeur 1996; LeMaitre 2002) and the Seychelles white-eye (Zosterops modestus) (Ward et al. 2007). Certain other endemic birds and indigenous organisms were also being considered for introduction, although these introductions have not been achieved to date. These potential include the Seychelles kestrel (Falco area), Seychelles black paradise flycatcher (Terpsiphone corvine), as well as the Robber crab (Birgus latro), which had largely disappeared from the Seychelles granitic islands probably as a result of human predation (Bowler 1999). During this phase, the Seychelles magpie robin was successfully introduced.

The introduction of the magpie robin went hand-in-hand with habitat restoration through removal of the alien plants and the replanting programme, all of which had the effect of increasing the available habitat, not just for these birds, but also for other endemic land birds, such as the Seychelles blue pigeon (Alectroenas pulcherrima), Seychelles sunbird (Nectarinia dussumieri) and the Seychelles fody (Foudia sechellarum) (the latter of which had reached about 470 birds by 1997). As this bird community is also dependent on invertebrate food resources, the restoration aimed to increase habitat for these resources, as well as providing for invertebrate conservation per se (Kelly and Samways 2003; Lawrence and Samways 2003).

During this phase of restoration was the confinement of agricultural plants (necessary for Cousine's sustenance) to a designated 0.3 ha horticultural area, and removal of domesticated plants outside this area. In some cases, such as Papaya (Carica papaya) and Soursop (Annona muricata), this has meant the ongoing removal of newly established plants which have grown from seeds dropped by various birds on the island. 
From 1995 onwards, chosen plants for propagation were established in a plastic/shade cloth covered tunnel from seeds or cuttings collected from both Cousine and from neighbouring islands. All cuttings were treated with the rooting hormone Seradix and given micro-jet irrigation. As part of the quarantine programme, there was no introduction of any bagged, rooted seedlings.

Planting took place during the north-west Monsoon rainy season (November-March). Temporary irrigation was put in place for some of the seedlings and cuttings that were exposed to the dry effects of the south-east Trade winds. Temporary shade-cloth barriers were also erected to protect some species of the plants from the adverse impact of salt spray. As 21 Aldabra giant tortoises (genetically mostly Dipsochelys dussumieri; see Gerlach 2004) had been introduced onto the island as a rescue operation for individuals caged or penned on the larger islands, sometimes under appalling conditions, it meant that nearly 2,000 of the seedlings had to be protected from tortoise grazing and trampling using logs from felled Casuarina and Coconut palm trees, and also using in total about 58,000 fallen coconuts to retain moisture around their bases. These products of the alien plant removal activities were therefore put to good use as protective collars around the newly established shrubs and trees.

A total of 2,543 trees and shrubs were planted mainly on the plain from 1993 to 2001 . These consisted of various species characteristic of lowland granitic Seychelles vegetation (Friedmann 1987; Robertson 1989). However, of particular note was the establishment of some Mapou trees (Pisonia grandis). Forests with this tree as a dominant species are extremely rare, and are certainly threatened as a forest type in the Seychelles. The point is that these trees are also a favoured nesting tree for the Lesser noddy (Anous tenuirostris) (Burger 2005). Besides encouraging the bird for its own sake, the planting of the Mapou trees and other species, once grown, would also produce a considerable leaf litter layer, which encourages colonization of forest invertebrates, which, in turn, provides food for the Seychelles magpie robin in particular (LeMaitre 2002).

During this second phase of restoration, a programme was introduced to monitor the growth of the seabird nesting populations, the increase in abundance of the introduced land birds and the increase in numbers of nesting turtles, especially the Hawksbill turtle. Also, various scientists were encouraged to visit the island to undertake various studies of key species and processes, such as reptiles (Bourquin and Hitchins 1998), Seychelles giant millipede biology (Lawrence and Samways 2003), assessment of the invertebrates of the leaf litter and logs (Kelly and Samways 2003), spider assessments (Saaristo 1999), colonization by dragonflies (Samways 1998, 2003a, b), Seychelles warbler (Komdeur 1994, 1995) and Seychelles magpie robin biology (Komdeur 1996; LeMaitre 2002), turtle biometrics and nesting biology (Hitchins et al. 2003a, b, 2004a, b, 2006), and marine assessments (Samways 2003a, $b$; Samways and Hatton 2001).

\section{The third phase}

The third phase was a natural extension of the second phase, and represents a change in management rather than any change in philosophy or direction. Besides, the trees on the plain had begun to naturally grow to form a closed canopy within a matter of only 10 years or so (Fig. 3). Nevertheless, at least another 755 trees were planted on the plain after 2001. One of the aims of this was to increase the diversity of plants, and hence dependent invertebrates as well. This ongoing planting programme will continue, especially along parts of the dune creast where Casuarinas have been removed, into the foreseeable future, with at 200 saplings of various species available at any one time for planting out.

Starting earlier but continuing during this third phase, shearwater, noddy and land bird numbers increased considerably, with the re-appearance in 2003, of the Sooty tern, after an absence of 31 years. Meanwhile the Seychelles magpie robin had increased to 39 birds and the Seychelles warbler to 350-400 birds, which contributed to its IUCN Red List status being downgraded from CR in 2000 to EN in 2007. In 2007, the Seychelles white-eye was introduced, and it immediately established 
very well, having already colonized much of the island, and started to breed (Jolliffe et al. 2007; Ward et al. 2007), and also contributing to its downlisting from CR to EN.

Cousine's contribution to the conservation of turtles has been enormous, with increasing numbers nesting on Cousine each year. There were, on average, 24 (19-43) nests per year from 1992 to 1995, increasing to 81 nests (66-108) per year from 1996 to 2006.

During this phase, there was a growing awareness that Cousine must also generate income to sustain the conservation effort and to open up Cousine's successes to the outside world. This led to the establishment of four villas on the island.

Of special note is that to this day, and without doubt partly arising from strict quarantine and control measures, there are no rats, mice nor crazy ants on Cousine.

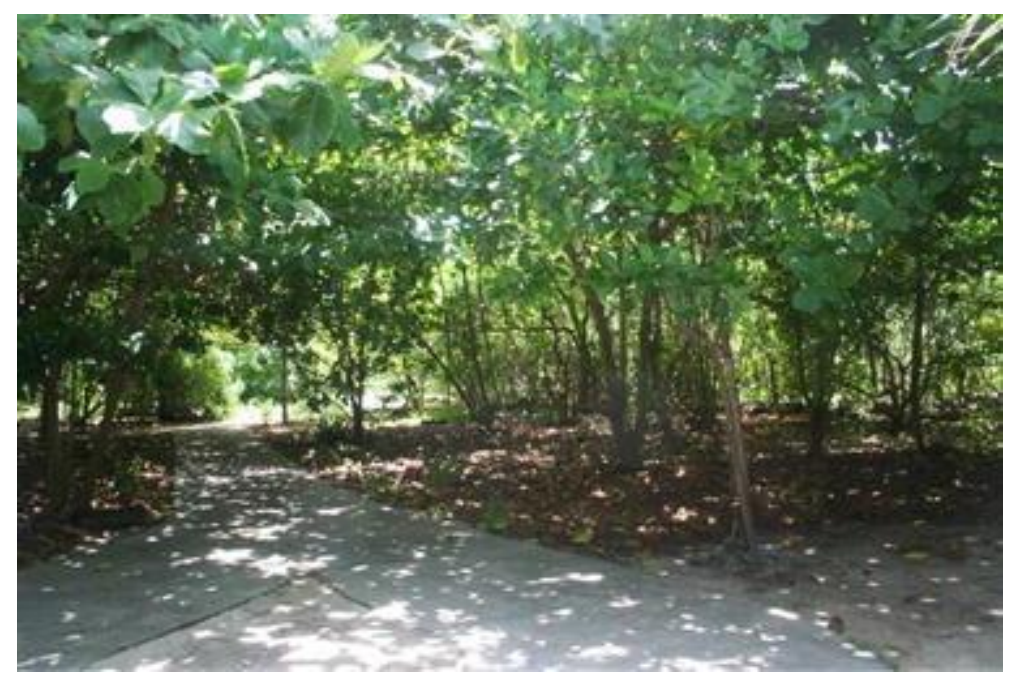

Fig. 3

The same view as in Fig. 2, but taken in 2007. The plain of Cousine Island has been largely cleared of alien vegetation and planted to indigenous trees which had already, within 10 years, formed a substantial canopy. This re-establishment of the coastal forest encouraged colonization by many invertebrates and various endemic and indigenous land and nesting sea birds

\section{Cousine: a bird's eye view}

Restoration is rarely final, and ongoing maintenance and monitoring activities are still often required. There were originally 78 species of alien plants on Cousine, of which 18 are cultivated. Of the 60 wild aliens ( 46 invasive and 14 non invasive), 25 have been eradicated, with the remainder in the process of being eradicated (17) or being controlled (26) - a remarkable achievement. When this, coupled with the increase in seabird, land bird, turtle and forest invertebrate numbers, we might well ask what have been the disadvantages of the restoration activity. First of all, not all invasive alien plants have been removed, although they are scheduled to be so. Nor have any invasive alien invertebrate been removed, although it is uncertain as to what is their ecological role, and whether in fact they are damaging. The Big-headed ant (Pheidole megacephala) is present in huge numbers, and in view of its adverse impact on other tropical islands, particularly in reducing endemic invertebrates, there is currently a research programme underway to ascertain its impact with the view to possibly eradicating it using the selective bait hydramethylnon. However, not all invasive alien invertebrates are deleterious. The Indian cockroach (Pycnoscelus indicus), for example, is a major food item for the Seychelles magpie robin.

Above all, the restoration programme has led to a shift in habitat type, with more forest and less open ground. Interestingly, this has been to the benefit of most of the endemic species. However, this habitat shift is, arguably, back to a more natural one. At least in terms of the invertebrates, most of those of the sunny coastal plain habitats are vagile generalists. Nevertheless, even their habitat is 
being kept open to some extent by the foraging behaviour of the tortoises, and certainly enough to maintain the African grass blue butterfly (Zizeeria knysna). Yet other sun-loving species have been lost to the island, such as the Common citril damselfly (Ceriagrion glabrum) and the Blue percher dragonfly (Diplacodes trivialis), which are both very common across wide continental areas.

However, these two species were not originally native to Cousine, as it had no open water. These, and some other species as well, only appeared on Cousine once artificial ponds for the tortoises had been established.

The original aim was to restore Cousine to its natural state (while accommodating humans to some extent). This has been very successful, with some species being deliberately introduced (tortoises, land bird and some plant species), while others have increased in abundance as a result of cessation of poaching, reduced disturbance and re-establishment of natural lowland forest or clearing of grassland (seabirds and forest invertebrates).

Cousine is also acting as precautionary ark for certain species. For example, it is not clear whether the Seychelles magpie or the Seychelles white-eye ever actually occurred on Cousine in historical times. Certain Seychelles endemic plants [Erthroxylum sechellarum, Mimusops sechellarum and Rothmannia annae; Bowler et al. (2000)] are also being maintained on the island. The philosophy of this could be argued extensively, but we must remember that Cousine is part of an archipelago. Only 17,000 years or so ago the inner grantic islands were connected as the sea level was more than $100 \mathrm{~m}$ lower than it is today (Camoin et al. 2004; Johnson and Baarli 2005). Thus, any modern assessment of which species were there is very likely the outcome of ecological relaxation as the islands came into flooded isolation.

There is the additional issue of the introduced tortoises of which the genetic pool collectively is largely the Aldabran tortoise, likely with some genetic stock from the endemic granitic Seychelles tortoises. None of the tortoises on Cousine have yet produced offspring and their presence is mostly one of animal care, although they may breed as they mature further. However, there is another viewpoint, and this posits that restoration is not just about compositional biodiversity but also functional biodiversity. It is likely that tortoises were present on Cousine in former times, especially when we consider the gradual changes that have occurred since the Pleistocene, at a time when Cousine was joined to neighbouring islands, and was therefore more extensive. The important point, however, is that the tortoises bring back a function to Cousine. They graze and trample the plateau vegetation, opening up some areas and provide sunlit habitats required by certain flying insects. They are also involved in the distribution of preferred plant species through ingestion and defaecation of seeds.

\section{Cousine's future}

A balance has been struck on Cousine between nature conservation and tourism. Cousine provides an experience which attracts certain tourists, some of whom come for the wildlife and others for the sun and solitude. This tourism also begets employment for the local people on Praslin and Mahé, who not only maintain the island but also supply the kitchen, with fish as well as fruits and vegetables. In turn, the island has extended a hand to neighbouring islands with the construction of an information and educational centre, based on Praslin, in a joint venture with its sister island Cousin, which is administered by Nature Seychelles.

Purist conservationists may well argue that this combining of people and nature on Cousine is not fully natural. But we have to be realistic, and Cousine must pay its way and integrate with the archipelago community. The restoration of Cousine has shown that people and nature can indeed be combined in a way that has a long-term future.

As with all small islands, there is a shortage of both water and fuel on Cousine. Tourism is demanding on both these commodities, as tourists to the island expect conditions equal or even better than what they experience at home. This is accommodated to a certain extent by using rainwater 
collected from the roofs, rather than putting demands on boreholes by excessive abstraction and risking salination of the freshwater lens. Roof-harnessed water is also generally more suitable for human consumption.

An additional consideration is that of the power supply for the island. Currently, there are diesel generators supplying the power, the fuel for which is pumped ashore from a supply ship. This is not acceptable as a long-term solution, as generators are a pollutant on the island. Furthermore, there is always risk of spillage as the fuel is pumped ashore. Thus, one of the major challenges, and currently being addressed, is to seek alternative power supplies, based on environmentally more acceptable methods. Should this be achieved, Cousine would have demonstrated to the world not only its value as a restored microcosm for an amazing array of wildlife and employment for people, but also would have earned its niche as a sustainable ecosystem of which future generations can be proud.

\section{Acknowledgments}

Restoration of an island is the product of a team effort, and in this regard we are very thankful for the enormous input from the local Seychellois people, and from many international volunteers. Also the restoration has benefited enormously from various inputs from Dylan Evans, Selwyn Gendron, Quentin and Debbie Hagens, Stella Hitchins (née Le Maitre), Frankie Hobro, Kevin and San-Marie Jolliffe, James Lawrence, Nirmal Jivan Shah and the late Danielle St Jorre.

\section{References}

Bahn P, Flenley J (1992) Easter Island: Earth Island. Thames and Hudson, London

Ball E (2001) Population density, distribution, habitat preference and relationship with nesting seabirds of the skinks Mabuya sechellensis and M. wrightii on Cousine Island, Seychelles. Unpublished MSc thesis, University College, London

Bourquin O, Hitchins PM (1998) Annotated checklist of the reptiles on Cousine Island, Seychelles. Afr Herp News 28:8-15

Bowler J (1999) The robber crab Birgus latro on Aride Island, Seychelles. Phelsuma 7:56-58

Bowler J, Bullock I, Cadbury J, Gerlach J, Hunter J (2000) Conservation status and management of Wright's gardenia Rothmannia annae. Phelsuma 8:23-27

Burger AE (2005) Dispersal and germination of seeds of Pisonia grandis, an Indo-Pacific tropical tree associated with insular seabird colonies. J Trop Ecol 21:263-271.

Camoin GF, Montaggioni LF, Braithwaite CJR (2004) Late glacial to post glacial sea levels in the western Indian Ocean. Mar Geol 206:119-146.

Diamond AW (1975) Cousine Island nature reserve management plan 1975-1979. BirdLife International, Cambridge. Unpublished Report

Friedmann F (1987) Flowers and trees of Seychelles. ORSTOM, Paris

Gerlach J (2004) Giant tortoises of the Indian Ocean. Andreas S. Brahm, Frankfurt am Main Hill M, Holm K, Vel T, Shah NJ, Matyot P (2003) Impact of the introduced crazy ant Anoplolepis gracilipes on Bird Island, Seychelles. Biodivers Conserv 12:1969-1984.

Hitchins PM, Bourquin O (1995) Cousine Island mission statement and management plan. Cousine Island, Internal Report, $7 \mathrm{p}$ 
Hitchins PM, Bourquin O, Hitchins S, Piper SE (2003a) Factors influencing emergences and nesting sites of hawksbill turtles (Eretmochelys imbicata) on Cousine Island, Seychelles, 1995-1999. Phelsuma 11:59-69

Hitchins PM, Bourquin O, Hitchins S (2003b) Inter-island nesting by hawksbill turtles (Eretmochelys imbricata) in Seychelles. Phelsuma 11:70-71

Hitchins PM, Bourquin O, Hitchins S, Piper SE (2004a) Biometric data on hawksbill turtles (Eretmochelys imbricata) nesting at Cousine Island, Seychelles. J Zool (Lond) 264:371-381.

Hitchins PM, Bourquin O, Hitchins S (2004b) Nesting success of hawksbill turtles (Eretmochelys imbricata) on Cousine Island, Seychelles. J Zool (Lond) 264:383-389.

Hitchins PM, Bourquin O, Hitchins S (2006) Distances covered and times taken for nesting of hawksbill turtles (Eretmochelys imbricata), Cousine Island, Seychelles. Phelsuma 13:93-101

Johnson ME, Baarli BG (2005) Erosion and burial of granite rocky shores in the recent and late Pleistocene of the Seychelles Islands: physical and biological perspectives. J Coast Res 21:867-879, 973.

Jolliffe K, Ward G, Jolliffe S-M, Henwood J (2007) Monitoring of the translocated Seychelles white-eye on Cousine Island. Internal Report of Cousine Island

Kelly J, Samways MJ (2003) Diversity and conservation of forest-floor arthropods on a small Seychelles island. Biodivers Conserv 12:1793-1813.

Klocke T, Klocke M (2006) Hidaway hotels: the 100 most beautiful hotels and resorts in the world. Klocke Publishing, Bielefeld

Komdeur J (1994) Conserving the Seychelles warbler Acrocephalus sechellensis by translocation from Cousin Island to the islands of Aride and Cousine. Biol Conserv 67:143-152.

Komdeur J (1995) Influence of helping and breeding experiments on reproductive performance in the Seychelles warbler: a translocation experiment. Behav Ecol 7:326-333

Komdeur J (1996) Breeding of the Seychelles magpie robin Copsychus seychellarum and implications for its conservation. Ibis 138:485-498.

Lawrence JM, Samways MJ (2003) Litter breakdown by the Seychelles giant millipede and the conservation of soil processes on Cousine Island, Seychelles. Biol Conserv 113:125-132.

LeMaitre S (2002) Food and density limitations of the Seychelles magpie robin Copsychus sechellarum, on Cousine Island. Ostrich 73:119-126

Miller JR (2005) Biodiversity conservation and the extinction of experience. Trends Ecol Evol 20:430434.

O'Dowd DJ, Green PT, Lake PS (2003) Invasional 'meltdown' on an oceanic island. Ecol Lett 6:445461.

Polis GA, Hurd SD (1996) Linking marine and terrestrial food webs: allochthonous input from the ocean supports high secondary productivity on small islands and coastal communities. Am Nat 147:396-423. 
Primack RB (2006) Essentials of conservation biology, 4th edn. Sinauer, Sunderland

Robertson SA (1989) Flowering plants of Seychelles. Royal Botanic Gardens, Kew

Saaristo MI (1999) Arachnid species lists for Silhouette, Cousine and Mahé. Phelsuma 7(Suppl A):112

Samways MJ (1998) Establishment of resident Odonata populations on the formerly waterless Cousine Island, Seychelles: an Island Biogeography Theory (IBT) perspective. Odonatologica 27:253258

Samways MJ (2000) A conceptual model of ecosystem restoration triage based on experiences from three remote oceanic islands. Biodivers Conserv 9:1073-1083.

Samways MJ (2003a) Conservation of an endemic dragonfly fauna in the Seychelles archipelago. Odonatologica 32:177-182

Samways MJ (2003b) Breakdown of butterflyfish (Chaetodontidae) territories associated with the onset of an intense coral bleaching event. Aquat Conserv Mar Freshwat Syst 15:5101-5107

Samways MJ (2007) Rescuing the extinction of experience. Biodivers Conserv 16:1995-1997.

Samways MJ, Hatton MJ (2001) An appraisal of two coral reef rapid monitoring manuals for gathering baseline data. Bull Mar Sci 69:471-485

Scheffer M, Carpenter SR (2003) Catastrophic regime shifts in ecosystems: linking theory to observation. Trends Ecol Evol 18:648-656.

Ward G, Jolliffe K, Jolliffe S-M, Henwood J (2007) Monitoring of the threatened Seychelles white-eye on Cousine Island. Internal Report of Cousine Island 